Original Article (short paper)

\title{
Early intervention program by ICF model for babies of 4-18 months frequenting daycare center: protocol for clinical trial
}

\author{
Tainá Ribas Mélo ${ }^{1,2}$, Luize Bueno de Araujo ${ }^{1}$, Bruna Yamaguchi1 ${ }^{1}$, Manoela de Paula Ferreira ${ }^{1}$, Vera Lúcia Israel $^{1,3}$ () \\ ${ }^{1}$ Universidade Federal do Paraná, Programa de pós graduação em Educação Física, Curitiba, PR, Brasil; \\ ${ }^{2}$ Instituto Brasileiro de Therapias e Ensino (IBRATE), Universidade Campos de Andrade (UNIANDRADE), \\ Curitiba, PR, Brasil, ${ }^{3}$ Universidade Federal do Paraná, Departamento de Fisioterapia, Curitiba, PR, Brasil
}

\begin{abstract}
Introduction: A daycare center is a long-term place for infants, which means that early intervention programs should be thought of in this environment. There are still many gaps regarding the best way of stimulation/ intervention, duration and description of effects and controlled outcomes. Aim: The objective of this clinical trial is to propose an early physical activity intervention program performed in infants of 4-18 months with risk/delay and with typical development at infant's daycare. Method: The protocol of this study is indicated for a controlled trial, in a crossover format, to be applied in 4 groups composed by in 4-18 month-old infants who attend daycare: Intervention group 1 Typical, Intervention group 1 Risk/delay, group Intervention 2 Typical, group Intervention 2 Risk/delay, in 4-18 month old infants who attend daycare. The ICF criteria about functions and structure (through evaluation questionnaire) are considered, as well as activities and participation (AIMS, Denver II, and PedsQlTM evaluation), personal characteristics (questionnaire, ABEP and AHEMD-IS) and environmental factors (AHEMD-IS). Conclusion: This original proposal can highlight a low-cost intervention program performed in a daycare environment verifying the infant's NMD in a systematized way using theoretical basis.
\end{abstract}

Keywords: physical therapy specialty, early intervention, child day care centers.

\section{Introduction}

Although the study on child development is not recent, the focus on neuromotor early intervention performed in a systematized using the theoretical basis is still scarce mainly in Brazil, and there are different gaps according to the type of intervention, duration, and description of controlled effects and outcomes. These aspects need to be investigated, considering that approximately 200 million children under 5 years old in developing countries, such as Brazil, are predisposed to neuromotor development (NMD) delay due to various factors such as poverty, lack of proper care and early stimulation ${ }^{1}$.

The exact prevalence of NMD delay is not known, some estimations are of 1 to $3 \%$ of the children population under 5 years old ${ }^{2}$, to $11 \%{ }^{3}$, to $31.2 \%$ of children of 0 to 3 years old ${ }^{4}$ from daycare centers. The unidentified NMD delay can lead to permanent disabilities in 5 to $10 \%$ of infants ${ }^{5}$, including learning difficulties in the school stage ${ }^{6}$. It is estimated $50 \%$ of children with special needs could have their NMD delay been avoided and/or minimized with early identification and intervention? These evaluations are relevant in a country like Brazil that still has high rates of school failure ${ }^{8,9}$ with repercussions on children's future development.

These data reinforce the relevance of early intervention programs on sensitive periods of development ${ }^{10}$ in which is intense of neuroplasticity, demonstrating improvements even in executive functions ${ }^{11}$, and being significant for use in clinical practice and the search for better evidence.

In the early stages of life, few studies performed regularly detailed early intervention ${ }^{12}$, but presented positive evidence of interventions carried out in enriched environments (with stimulation and/or orientations $)^{13}$ like home and/or school ${ }^{7,14}$.

In this way, these early intervention programs should be planned in the infant's living environments such as the daycare center is in a long-term place for infants. Taking in consideration the socio-economic transformations of society and the insertion of women in the labor ${ }^{7}$, from 1998 to 2008, the rate of enrollment in infant's daycare increased, reaching $18 \%$, but with unsatisfactory quality in most institutions about to the activities developed and stimulation offered ${ }^{8}$.

It is necessary to consider the biopsychosocial health model based on the International Classification of Functioning, Disability, and Health (ICF), and to understand the infant development as complex and dependent on the individual's relationships with the environment and with the stimulus received ${ }^{15}$. However, finding in the literature studies that bring early intervention protocols to be reproduced in clinical or daycare settings still present as a gap.

Therefore, this clinical trial aims to propose an early physical activity intervention program performed in infants of 4-18 months with risk/delay and with typical development at infant's daycare. 


\section{Methods}

\section{Trial design}

The protocol is for a blinded interventional clinical trial, in a crossover design as indicated by Standard Protocol Items: Recommendations for Interventional Trials (SPIRIT) guidelines $^{16}$.

The research was approved by the Federal University of Paraná (UFPR) Ethics Committee, CAAE: 57193516.6.0000.0102. All items from the World Health Organization (WHO) Trial Registration Data Set were registered at the Brazilian Registry of Clinical Trials (RBR 2hd6sm) ${ }^{[1]}$. This is an intervention program to be carried out on infants of 4-18 months attending daycare centers.
Considering the value of children 0-4 years as approximately 107,000 children $^{17}$ in Curitiba (Parana-Brazil), with an estimated total of 50,000 infants in daycare centers/schools (Curitiba Department of Education) and considering an estimation of delay in the NMD of $30 \%$, we considered the sample calculation formula assuming a sampling error of $10 \%$ and taking 4 measurements repeated for the main outcome, we obtained $n=52$ of the sample size calculation, allocated in Intervention group 1 Typical $(n=20)$, group Intervention 2 Typical $(n=20)$, group Intervention 1 Typical $(\mathrm{n}=6)$, group Intervention 2 Typical 2 $(\mathrm{n}=6)$, with study performed in a cross-over design, assuming effect size $0.25^{18}$, type I error 0.05 , analysis power of 0.95 .

The randomization will be done considering the daycare center because each round of intervention is done between 2 daycare centers (Figure 1).
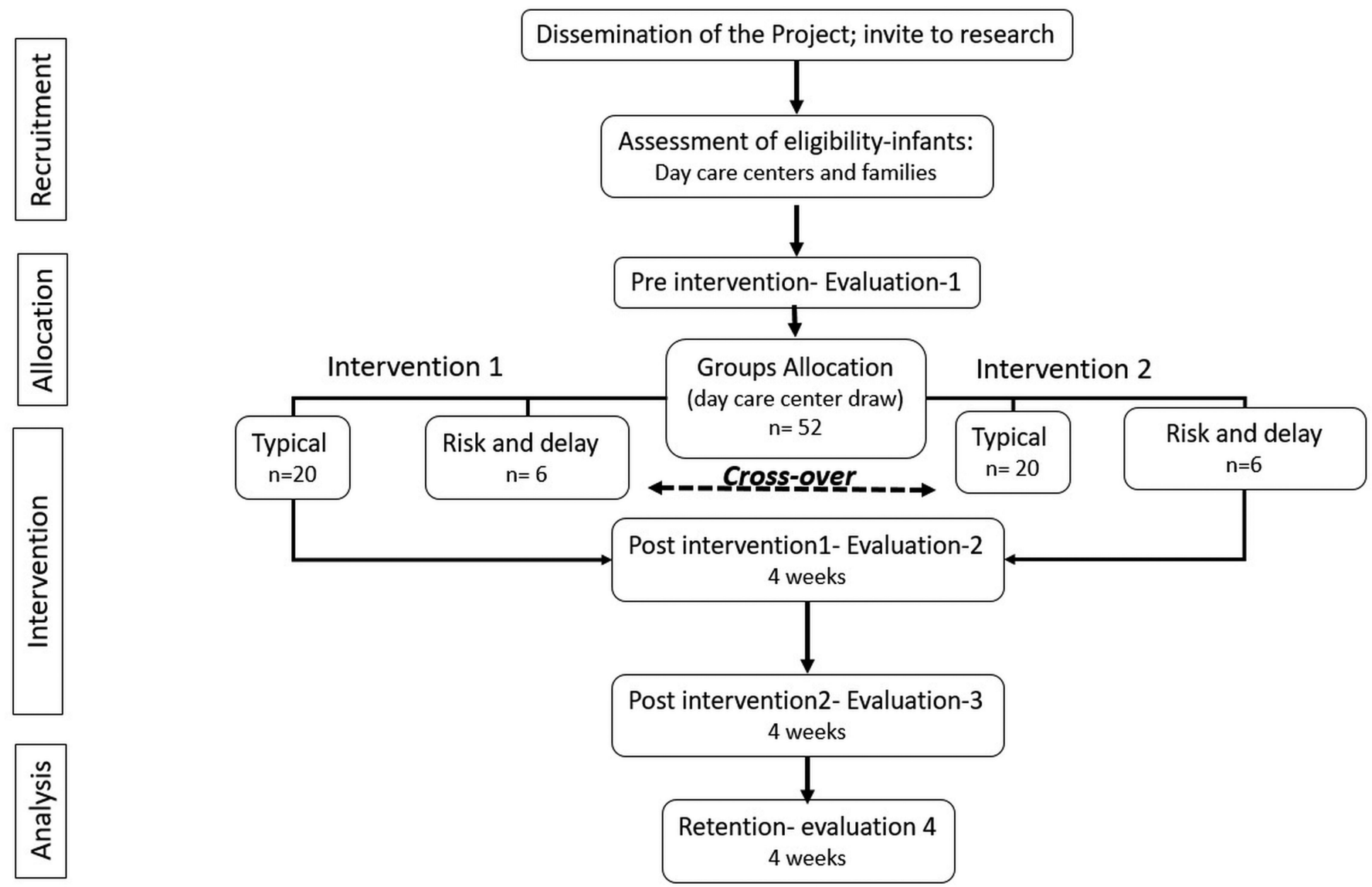

Figure 1. Flow diagram of the study.

As the numbers of infants at risk/delay are not known, a pilot study was performed, obtaining a ratio of 1:3 of risk/delay: typical development in 2 daycare center previous evaluated.

\section{Study setting}

The infants included in this study will be those aged 4-18 months old, both sexes ${ }^{19}$ attending public and/or contracted daycare centers in Curitiba (Paraná, Brazil), in a nearby location to have similar local socioeconomic criteria. Also as inclusion criteria the infants should have the consent of the parents/family and be a registered, and who do not participate in any motor or cognitive intervention program ${ }^{20}$. Infants with illnesses and/or associated disability ${ }^{6,14,21}$ will be excluded from the study analysis, although they may participate in the intervention program in case of parental interest.

Babies aged 4-18 months will be screened by AIMS and Denver II to identify the risk/delay babies and those with typical development. The 4 months old is the minimum acceptable age in the daycare environment and when the babies can be analyzed by various domains of the ICF with specific validated scales. 
Babies will be classified at risk with suspicious percentiles $(<25)$ and delay with atypical percentile $(<5)$ by $\mathrm{AIMS}^{22}$. For Denver II, are considered typical if present up to 1 caution, questionable (at risk) if they present up to 1 fault and 1 caution or 2 cautions and delay if they have more than 1 fault and/or 2 or more cautions ${ }^{23}$.

\section{Intervention groups}

Aiming to favor the ecological model, in the habitual context of the babies, they will be evaluated and will receive intervention in the daycare ${ }^{20}$.

The intervention will be carried out in both daycare centers. The Intervention groups- 1 will be composed by the infants in the daycare, who will receive the intervention at first, and the Intervention groups- 2 will receive the intervention after 8 weeks. Although all groups will be followed by blinded researches at the same days during the study to blind the researches and to keep the bond with the infants. The intervention program will be conducted by physiotherapists with experience in the area, assisted by academics of Physical Therapy. After data collection, the 4 groups will be analyzed.

\section{Early Intervention Program (EIP)}

Firstly, all technical team (evaluator and the researchers who will apply the intervention) should be familiarized with the infants and the daycare staff.

Regarding the time and dosage of intervention, the present proposal consisted of interventions performed $2 \mathrm{x}$ /week for 4 weeks, based on studies suggestions ${ }^{20,24}$. Each intervention program is interleaved for a period of 2 weeks of reevaluation, and for a period of 1 detraining month (retention). Each intervention lasts from 40 minutes to 1 hour $^{24}$. And as this is a cross-over design, the implementation of the entire intervention program will last 1 semester.

The critical and important points to be investigated in infants are development of motor skills (motor proficiency, gross motor skills, locomotion and control of the object) and cognitive development (language and attention/personal-social) ${ }^{25}$.

In order to standardize and systematize the intervention program, activities were developed according to specific functional objectives for expected motor behavior for each age group ${ }^{26-29}$ in three main axes: locomotor, stabilizer and manipulative (Table 1). The manipulative axis is associated with activities that stimulate language and cognition.

Table 1. Early Intervention Program (EIP) based on motor milestones incentive

\begin{tabular}{|c|c|c|c|c|}
\hline \multirow{4}{*}{ 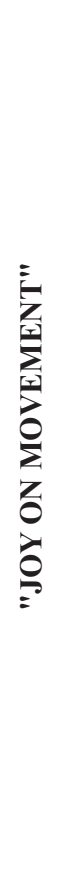 } & Names & AXIS & Functional Objective/Motor behavior & Activities \\
\hline & $\begin{array}{l}\text { Heats up } \\
\text { Move yourself! }\end{array}$ & Locomotor & $\left.\begin{array}{l}\text { 1- Rolling } \\
\text { 2- Crawling } \\
\text { 3- Sitting } \\
\text { 4- Kneeling } \\
\text { 5- Walking with support } \\
\text { 6- Walking without support }\end{array}\right\} 12 \mathrm{~m}$ or + & $\begin{array}{l}\text { Locomotor activities in circuit of global } \\
\text { motricity, in which some activities of } \\
\text { equilibrium (stabilizers) and manipulatives } \\
\text { can be associated. Encourage the most } \\
\text { complex motor behavior possible. } \\
\text { Activities described in the intervention } \\
\text { program/Activities program. } \\
\text { Stimulation of motor coordination, beginning } \\
\text { of body notion of body, equilibration. }\end{array}$ \\
\hline & $\begin{array}{l}\text { Lift-fall-lift } \\
\text { Balance! }\end{array}$ & Stabilizer & $\left.\begin{array}{l}\text { 7- Puppy } \\
\text { 8- Sitting } \\
\text { 9- } 4 \text { points }\end{array}\right\} 4-11 \mathrm{~m} 29 \mathrm{~d}$ & $\begin{array}{l}\text { Balancing activities: stable postures vs } \\
\text { unstable postures and posture transfers, } \\
\text { associated with manipulative activities (fine } \\
\text { motor). Use surface variation as a form of } \\
\text { graduation of the difficulty and progression } \\
\text { of the exercises. }\end{array}$ \\
\hline & Get to work! & $\begin{array}{c}\text { Manipulative } \\
\text { Cognitive and Language }\end{array}$ & $\left.\begin{array}{l}\text { A-Catch up } \\
\text { B- Manipulate } \\
\text { C- Release } \\
\text { D-Play } \\
\text { E- Push } \\
\text { F- Fit in }\end{array}\right\}$ all & $\begin{array}{l}\text { Fine motor activities performed in } \\
\text { association with Locomotor and balance } \\
\text { (stabilizing) activities with a degree of } \\
\text { difficulty and adequacy to age and the } \\
\text { most withplex motor behavior possible. } \\
\text { Use as a phase of return to calm, stimulate } \\
\text { concentration and joint use of language. }\end{array}$ \\
\hline
\end{tabular}

The babies will be scored in each session, for follow-up according to the following score

Score:

\begin{tabular}{|l|l|}
\hline 1 & Do not do or reject; failed \\
\hline 2 & Partial: makes some mistakes; facilitated and/or assisted \\
\hline 3 & Total: Do and correct; passed on \\
\hline
\end{tabular}

Source: planned information based on multiple authors ${ }^{23-26}$ 
In Table 2 the motor behaviors were codified in infant motor functions to facilitate understanding at the time of the activity description and are presented during for 4 weeks.

For the axis of locomotive activities, the motor behaviors encourage are rolling, crawling, sitting, crawling, walking with support and walking without support, according to the age groups, but being allowed shadowing because of the abilities presented by the babies.

For the stabilizing axis, the motor behaviors stimulated are staying in puppy, sitting, on 4 supports, kneeling or semikneeling, standing and squatting.

Regarding the axis of manipulative activities associated with language and cognitive functions, the motor behaviors encouraged are reach, manipulate, release, play, push and fit, with different degrees of difficulty.
In each week, the progression of activities occurs due to the increase of the support surface: firm, soft, different textures and inclined, and the activities and their progression are described in Table 2.

In order to favor interaction and exploration of the environment, besides allowing a warm up, during the initial 5 minutes the exploration is free considering the babies' agitation at the beginning. This 5-minutes warm-up time considered is indicated in studies in children and adolescents ${ }^{30}$, although there is no specific definition of this parameter for infants.

Stabilizing and manipulative activities will always be performed at the end of the intervention, so it is recommended to perform these activities at the same time to "turn back" the calm until the circuit is finished.

Table 2. Organization of the Early Intervention Program (EIP) with a description of the activities

\begin{tabular}{|c|c|c|c|c|c|c|c|c|c|c|c|}
\hline \multirow{3}{*}{$\frac{\pi}{2}$} & \multirow{2}{*}{\multicolumn{2}{|c|}{$\begin{array}{c}\begin{array}{c}\text { Expected motor } \\
\text { behavior }\end{array} \\
\text { Age Group } \\
\end{array}$}} & \multirow{3}{*}{$\stackrel{\mathscr{\Xi}}{.}$} & \multirow{2}{*}{\multicolumn{2}{|c|}{$\begin{array}{c}\text { 1st WEEK } \\
\text { Firm surface }\end{array}$}} & \multirow{2}{*}{\multicolumn{2}{|c|}{$\begin{array}{l}\text { 2nd WEEK } \\
\text { Soft surface }\end{array}$}} & \multirow{2}{*}{\multicolumn{2}{|c|}{$\begin{array}{l}\text { 3rd WEEK } \\
\neq \text { textures }\end{array}$}} & \multicolumn{2}{|c|}{ 4th WEEK } \\
\hline & & & & & & & & & & Foam/inclin & ned surface \\
\hline & $4 \mathrm{~m}-11 \mathrm{~m} 29 \mathrm{~d}$ & $12 \mathrm{~m}$ or + & & 4m-11m29d & $12 \mathrm{~m}$ or + & 4m-11m29d & $12 \mathrm{~m}$ or + & 4m-11m29d & $12 \mathrm{~m} \mathrm{or}+$ & 4m-11m29d & $12 \mathrm{~m} \mathrm{or}+$ \\
\hline \multirow[b]{2}{*}{ 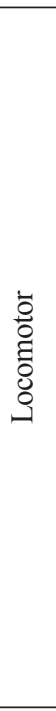 } & \multirow[b]{2}{*}{$\begin{array}{l}\text { 1- Rolling } \\
\text { 2- Crawling } \\
\text { 3- Sitting }\end{array}$} & \multirow{2}{*}{\multicolumn{2}{|c|}{ 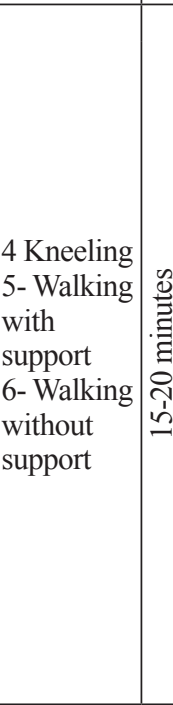 }} & \multicolumn{8}{|c|}{ Warm-up (5 minutes): Give command of circuit activity and demonstrate; guide and speak to wait your turn. } \\
\hline & & & & $\begin{array}{l}\text { 1- Rolling: } \\
\text { Prone to } \\
\text { supine on } \\
\text { carpet (Firm } \\
\text { surface) } \\
\text { for object } \\
\text { direction } \\
\text { 2- Crawling: } \\
\text { on Firm } \\
\text { surface, } \\
\text { inside the } \\
\text { tunnel, box } \\
\text { or sheet } \\
\text { (MUSIC) } \\
\text { 3- Sitting: on } \\
\text { Firm surface }\end{array}$ & $\begin{array}{l}\text { 4- Kneeling: } \\
\text { on carpet } \\
\text { (Firm } \\
\text { surface) } \\
\text { (MUSIC) } \\
\text { 5- Walking } \\
\text { with } \\
\text { support: on } \\
\text { Firm surface } \\
\text { and/or } \\
\text { 6- Walking } \\
\text { without } \\
\text { support: on } \\
\text { Firm surface }\end{array}$ & $\begin{array}{l}\text { 1- Rolling: } \\
\text { Prone to } \\
\text { supine + } \\
\text { supine to } \\
\text { prone (soft } \\
\text { surface) } \\
\text { for object } \\
\text { direction } \\
\text { 2- Crawling: } \\
\text { on soft } \\
\text { surface } \\
\text { inside the } \\
\text { tunnel, box } \\
\text { or sheet } \\
\text { (MUSIC) } \\
\text { 3- Sitting: on } \\
\text { soft surface }\end{array}$ & $\begin{array}{l}\text { 4- Kneeling: } \\
\text { on carpet } \\
\text { (soft } \\
\text { surface) } \\
\text { (MUSIC) } \\
\text { 5- Walking } \\
\text { with } \\
\text { support: on } \\
\text { soft surface } \\
\text { and/or } \\
\text { 6- Walking } \\
\text { without } \\
\text { support: on } \\
\text { soft surface }\end{array}$ & $\begin{array}{l}\text { 1- Rolling: } \\
\text { Prone to } \\
\text { supine + } \\
\text { supine to } \\
\text { prone with } \\
\text { \# textures } \\
\text { for object } \\
\text { direction } \\
\text { 2- Crawling: } \\
\text { on } \neq \text { textures } \\
\text { surface } \\
\text { inside the } \\
\text { tunnel, box } \\
\text { or sheet } \\
\text { (MUSIC) } \\
\text { 3- Sitting: } \\
\text { on } \neq \text { textures } \\
\text { surface }\end{array}$ & $\begin{array}{l}\text { 4- Kneeling: } \\
\text { on carpet } \\
\text { with } \neq \\
\text { textures } \\
\text { (MUSIC) } \\
\text { 5- Walking } \\
\text { with } \\
\text { support: on } \\
\neq \text { textures } \\
\text { surface } \\
\text { and/or } \\
\text { 6- Walking } \\
\text { without } \\
\text { support: on } \\
\text { f textures } \\
\text { surface }\end{array}$ & $\begin{array}{l}\text { 1- Rolling: } \\
\text { Prone to } \\
\text { supine + } \\
\text { supine } \\
\text { to prone } \\
\text { on foam } \\
\text { for object } \\
\text { direction } \\
\text { 2- Crawling: } \\
\text { on inclined } \\
\text { surface } \\
\text { inside the } \\
\text { tunnel, box } \\
\text { or sheet } \\
\text { (MUSIC) } \\
\text { 3- Sitting: } \\
\text { on inclined } \\
\text { surface } \\
\end{array}$ & $\begin{array}{l}\text { 4- } \\
\text { Kneeling: } \\
\text { on foam } \\
\text { 5- Walking } \\
\text { with } \\
\text { support: } \\
\text { on inclined } \\
\text { surface } \\
\text { and/or } \\
\text { 6- Walking } \\
\text { without } \\
\text { support: } \\
\text { on inclined } \\
\text { surface }\end{array}$ \\
\hline \multirow[b]{2}{*}{ 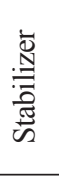 } & \multirow[b]{2}{*}{$\begin{array}{l}\text { 7- Puppy } \\
\text { 8- Sitting } \\
\text { 9- } 4 \text { points }\end{array}$} & \multirow{2}{*}{$\begin{array}{l}\text { 10- High } \\
\text { kneeling } \\
11-\text { Stand } \\
12- \\
\text { Squatting }\end{array}$} & \multicolumn{9}{|c|}{ Return to calm! Request concentration, talk to get organized in circles and wait your turn. Dropping and lifting } \\
\hline & & & & & & & & & & & \\
\hline 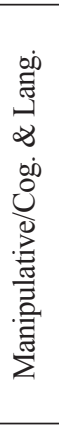 & $\begin{array}{l}\text { A- Catch } \\
\text { up } \\
\text { (balls; } \\
\text { mirror; } \\
\text { suction } \\
\text { cup; object } \\
\text { ahead) } \\
\text { B- } \\
\text { Manipulate } \\
\text { C- Release } \\
\text { (rings; } \\
\text { cubes) } \\
\end{array}$ & $\begin{array}{l}\text { D-Play } \\
\text { (balls, } \\
\text { cubes) } \\
\text { E- Push } \\
\text { (car) } \\
\text { F- Fit in } \\
\text { (Lego, } \\
\text { Objects in } \\
\text { Box) }\end{array}$ & 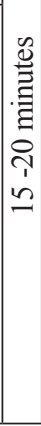 & $\begin{array}{l}\text { 7- puppy } 1 \\
+ \text { A } \\
\text { 8- Sitting }+ \\
\text { AB } \\
\text { 9- } 4 \text { points } \\
+ \text { AB }\end{array}$ & $\begin{array}{l}\text { 10- High } \\
\text { kneeling + } \\
\text { AB } \\
11 \text {-stand + } \\
\text { AB } \\
12- \\
\text { squatting + } \\
\text { AB }\end{array}$ & $\begin{array}{l}\text { 7- puppy } 2 \\
+ \text { BC } \\
\text { 8- Sitting + } \\
\text { BC } \\
\text { 9- } 4 \text { points } \\
+ \text { BC }\end{array}$ & $\begin{array}{l}\text { 10-High } \\
\text { kneeling + } \\
\text { BC } \\
11 \text {-stand + } \\
\text { BC } \\
12 \text { - } \\
\text { squatting + } \\
\text { BC }\end{array}$ & $\begin{array}{l}\text { 7- puppy } \\
\text { release one } \\
\text { hand + DE } \\
\text { 8- Sitting + } \\
\text { DE } \\
\text { 9- } 4 \text { points } \\
+ \text { DE }\end{array}$ & $\begin{array}{l}\text { 10- High } \\
\text { kneeling + } \\
\text { DE } \\
11 \text {-stand + } \\
\text { DE } \\
12 \text { - } \\
\text { squatting + } \\
\text { DE }\end{array}$ & $\begin{array}{l}\text { 7- puppy } \\
\text { release } \\
\text { both hands } \\
\text { alternately } \\
+\mathbf{F} \\
\text { 8- Sitting }+\mathbf{F} \\
\text { 9- } 4 \text { points } \\
+\mathbf{F}\end{array}$ & $\begin{array}{l}\text { 10- High } \\
\text { kneeling } \\
+\mathbf{F} \\
11 \text {-stand } \\
+\mathbf{F} \\
12- \\
\text { squatting } \\
+\mathbf{F}\end{array}$ \\
\hline
\end{tabular}

Score:

\begin{tabular}{|l|l|l|l|}
\hline 1 & Do not do or reject; failed & 2 & Partial: makes some mistakes; facilitated and/or assisted \\
\hline
\end{tabular} 3 Do and correct; passed on 
The materials used in the intervention are mostly available in the daycare center, with some low-cost resources added by the researchers and used in both daycare centers, to standardize the intervention. Examples of activities and materials used can be seen in Figure 2 (EVA, mats, foams, different texture mats, balls of different sizes and textures, water-filled balls, docking toys, rings, mirror fixtures, toys with (week 1) for soft (week 2), with different textures (week 3 ) and on foam surface and slope (week 4), and better described in Table 2.

In the absence of a specific instrument to control the evolution of the elaborated protocol, and in order to obtain an individual control, a quantification was elaborated by the authors of this study, considering 1- failed, does not do or reject; 2-partially, does with some errors, facilitated and/or with help and 3-totally: does and hits, passed. These scores help the individual participation control as well as evolution and frequency control.

The collective activity is based on neuroplasticity and learning issues. Concerning to motor learning, it is recognized that mental practice and observation of movement can activate mirror neuron circuits helping motor activity to be imitated more easily, not replacing, the execution of the movement ${ }^{31}$, but facilitating the process of activating an internal motor program using memory ${ }^{32}$. These presuppositions justify the benefits offered in collectively therapies done to favor motor learning by "mirroring" their peers, favoring the activation of mirror neurons.

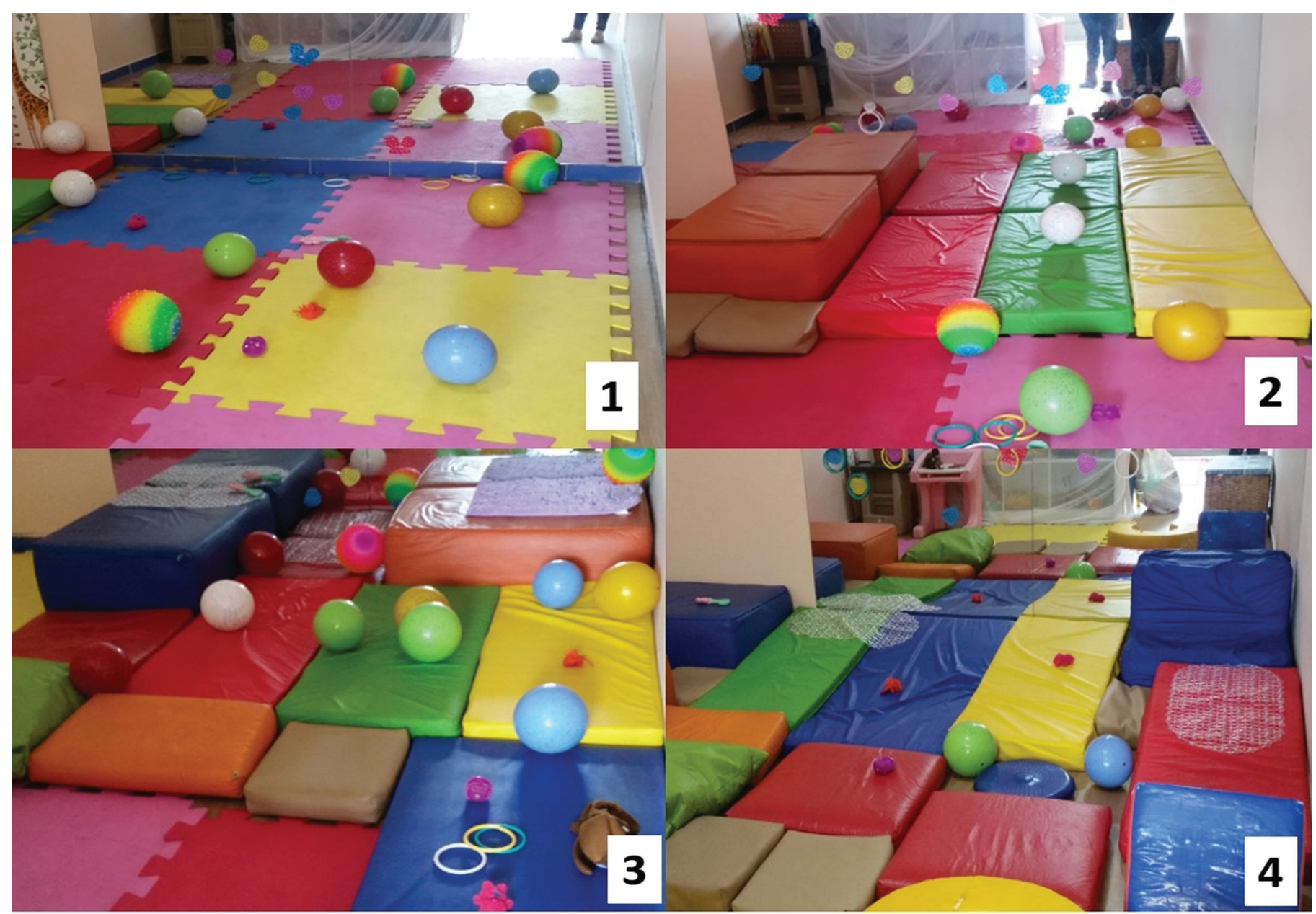

Figure 2. Examples of activities performed per week (1: firm surface, 2: soft surface, 3: different textures, 4: foam/sloped surface)

\section{Control Group}

The control group will be composed of infants who attend daycare centers, both at-risk/delay and with typical development who are not receiving intervention at the time of comparison. This is to ensure that the influence of the daycare environment on development is the same for all groups. In this way, in the first reassessment, the Intervention groups 2 (Risk/Delay and Typical) will be the control group for Intervention groups 1 (Risk/Delay and Typical), in order to comply with ethical principles, the control groups will initially receive intervention in the subsequent period, following the steps of a cross-over study.

\section{Evaluations}

For both primary and secondary outcomes, evaluations will be conducted in the daycare setting and organized to respond to ICF domains (Figure 3$)^{33}$. 
The ICF criteria about functions and structure (through evaluation questionnaire) are considered, as well as activities and participation (AIMS, Denver II and PedsQ1 ${ }^{\mathrm{TM}}$ evaluation in the school environment), personal characteristics (through a family questionnaire, ABEP, and AHEMD-IS) and environmental factors (AHEMD-IS).

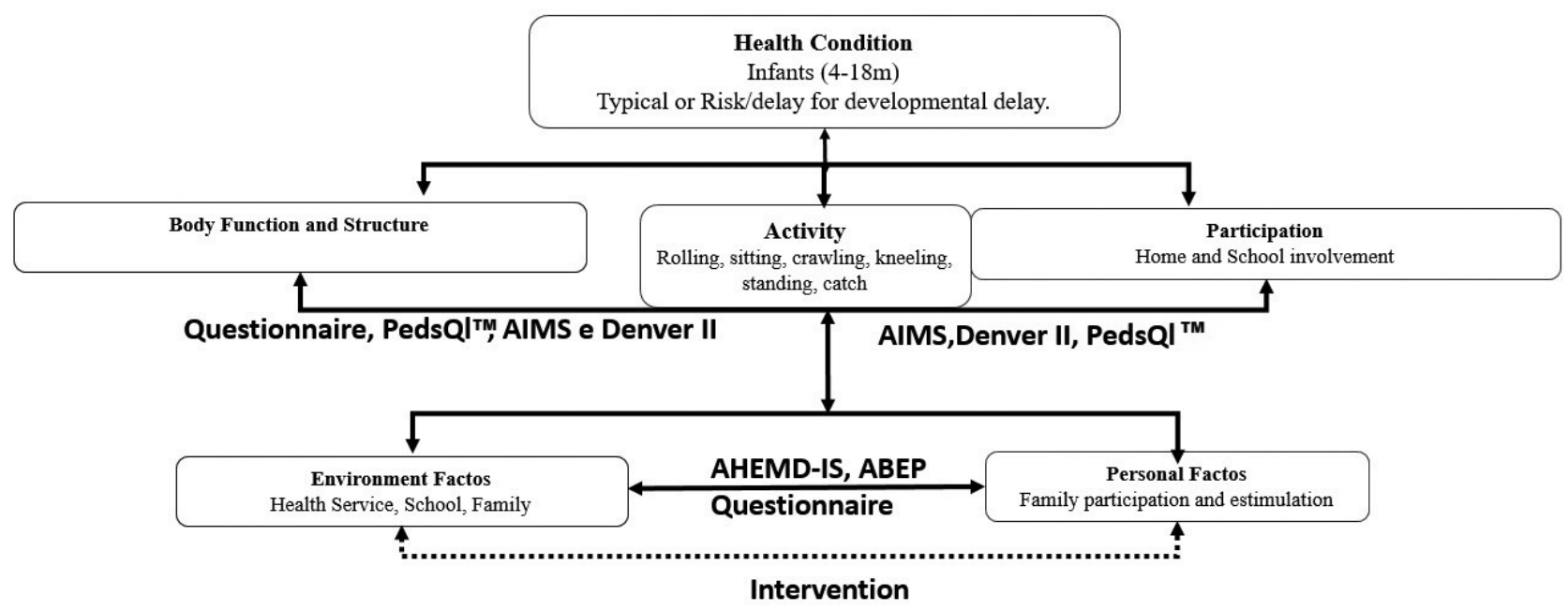

Figure 3.Organization of the evaluation scales by the ICF model.

\section{Primary outcomes}

The primary outcomes are the infant development using the AIMS and Denver II score.

For the primary endpoint, infants will be evaluated at 4 times using AIMS and Denver II. In the first evaluation will be defined the babies at Risk/Delay and those with typical development of each daycare. The same instruments will be used in 3 more moments to verify the effect of the intervention and retention.

The Denver II test is a validated instrument ${ }^{23,34}$ which allows psychomotor screening in the motor (thick and thin), personalsocial, language and adaptive-cognitive domains, presents low cost, quick and easy application, with an average time of 20-30 minutes of evaluation, by the observation of specific items the assessed age, in each area / area of the scale 5, for this is drawn a vertical line and it is verified which items should be evaluated ${ }^{34,35}$.

As already mentioned by Denver II are considered typical if they present up to 1 caution, questionable if they present up to 1 fault and 1 caution or 2 cautions and delay if they have more than 1 fault and/or 2 or more cautions ${ }^{23}$. These criteria will be used in order to verify if there was a change of this classification from the initial moment in comparison to the moments after the intervention.

Because this instrument is not as specific about motor issues in the first 6 months of life, infants will also be evaluated by the Alberta Infant Motor Scale (AIMS) ${ }^{22,36}$ utilizing observation of spontaneous movements of the baby, alignment and contact surface in 4 postures (prone, supine, sit and standing), without restrictions, without manipulation and/or facilitation, but encouraged to spontaneous movement in babies from 1 st to 18 th month. At the end, the points in each observed posture are summed in a total score of the observed items, being related to the age and baby's score to be plotted its percentile ${ }^{37}$.
The AIMS is a low-cost, easy-to-use protocol for direct observation of the baby, with an average duration of 30 to 40 minutes, with spontaneous antigravitational movements being observed freely, without evaluator facilitation, postural alignment, and contact surface prone, supine, sitting and standing positions $^{38}$. AIMS Brazilian percentiles are classified into motor development categories: below $5 \%$, the baby is considered to have atypical motor performance or delay; between $5 \%$ and $25 \%$, is considered as suspect or at risk; and above $25 \%$, is typical $^{39}$, and new percentiles were added and validated for the Brazilian population, with the addition of the percentile 1 that characterizes the baby as atypical and the 99th percentile, which characterizes a maximum motor performance ${ }^{22}$.

\section{Secondary outcomes}

The secondary outcomes were quality of life and stimulation received, with socio-economic issues as a control.

These evaluations will be performed in three moments: pre-intervention, post-intervention 1 (evaluation 2) and postintervention 2 (evaluation 3), not being performed at the moment of retention.

In order to complement the understanding of the aspects that involve NMD and considering the influence of the environment and the stimulation on the NMD, The Affordances in the Home Environment for Motor Development (AHEMD-IS) is used to investigate questions regarding ICF contextual factors ${ }^{40}$, for qualitative and quantitative verification of motor enrichment opportunities in a family environment (environmental factors) $)^{12}$, as well as to verify socio-economic, educational factors of parents and the stimulation they offer to infants at home related to the variety of stimulation, physical space, global motricity toys, and fine motor toys. 
For the quality of life outcomes ${ }^{41,42}$ the Pediatric Inventory of Quality of Life (PedsQL ${ }^{\mathrm{TM}}$ ) will be used, in the version of 1-12 months and another of 13-24 months, interviewing the parents and/or caregivers ${ }^{43}$ contemplating the outcomes indicated by the ICF. Both instruments are used through interviews with the relatives and carried out by the same evaluator of the babies in 3 moments (Moments 1, 2 and 3 already described).

Parents' socioeconomic and educational factors on NMD ${ }^{44,45}$ will also be evaluated by the socioeconomic questionnaire of the Brazilian Association of Research Companies for Brazil-ABEP ${ }^{46}$.

\section{Statistical analyses}

Descriptive measures will be calculated for the quantitative variables: averages, sample size, standard deviation, minimum and maximum. For the qualitative variables will be constructed contingency tables, by class/group, with the frequency of responses.

Initially, the data will be treated with standard descriptive statistics (mean and standard deviation) and will have the distribution normality and the homogeneity of the variances tested by the Shapiro-Wilk and Levene tests, respectively.

Regarding the effects of the intervention, when the data present normal distribution, corresponding parametric statistics will be used. The t-test will be applied to compare the characteristics of the participants (mass, height and age). The ANOVA test for analysis and comparison of parametric data.

If the data are non-parametric, to compare the groups concerning to the scores, the non-parametric Mann Whitney test will be used. In order to compare the combined groups with the results, the non-parametric Kruskal Wallis tests, complemented by the DMS test (minimum significant difference) will be applied to the scores. To compare the development of the infants along the observation moments, the Friedman test will be applied, complemented by the DMS test.

For comparisons made between groups, Chi-square tests, Kruskal Wallis test, Mann Whitney test, and Fisher's exact test will be used for the independent variables.

\section{Discussion}

This research will provide subsidies for the implementation of an early intervention program to contemplate fundamental outcomes to neuromotor development and secondary outcomes in order to respond to the domains of activities and participation, environmental and personal factors as advocated by ICF model.

With the socioeconomic transformations of society and the insertion of women into the labor market, the daycare center in Brazil is now a long-stay system (8-10h/day) for infants and children from zero to six years old ${ }^{7}$. Better results are expected in the process of identification/evaluation and intervention of risk situations and/or delay in infants up to 18 months, considered a period critical to development ${ }^{1,47,48}$.
Early interventions with infants with delays and/or neuromotor disorders rarely seem to have positive effects on their motor repertoire when performed alone, however when associated with enriched environments these effects appear to have significant effects ${ }^{13}$, and $50 \%$ of these delays could be avoided and/or minimized with early interventions ${ }^{7}$.

Thus, it is necessary to organize and standardize models of intervention programs that consider all domains of ICF in a systematized form and with systematized follow-up tools to respond to the outcomes of promoting children development and adequate NMD that can be performed at low cost due to the Brazilian reality. These programs can be performed and optimized in the infant's proximal environment, as a daycare institution, considering their evaluation as well as the environment about to the daycare and home environment.

As parameters for such programs are still not well established in the literature, this present proposal of intervention presents a systematization and intervention organization for infants in order to establish these parameters, related to locomotion, stabilizing and manipulative activities.

This proposal may also allow the articulation between the sectors of Education and Health, facilitating the early identification of risk situations, and favoring the scope of the intervention program, in pursuit of the promotion of infant development and in accordance with the Legal Framework of Early Childhood in Brazil (2016) that aims: to value and attenuate the initial phase of life, considering the first 1000 days or 24 months ${ }^{49}$ and which can be expanded and adapted to other locations.

The Early Childhood Legal Framework is based on four simple principles that countries can follow in designing and implementing successful Early Childhood Development strategies: (1) preparing diagnosis and strategy; (2) largely implement infant development by coordination; (3) create synergies and reduce costs using integrated interventions; and (4) monitor, evaluate and scale up successful interventions ${ }^{49}$. The early intervention program proposed here meets these principles.

\section{Trial status}

A pilot study was conducted to organize the intervention program and estimate the Risk/Delay vs Typical development, and this study is currently in the intervention phase.

\section{Endnote}

[1] www.ensaiosclinicos.gov.br/rg/RBR-2hd6sm/

\section{References}

1. Grantham-McGregor S, Cheung YB, Cueto S, Glewwe P, Richter L, Strupp B, et al. Developmental potential in the first 5 years for children in developing countries. The lancet. 2007;369(9555):60-70. http://dx.doi.org/10.1016/S0140-6736(07)60032-4 
2. Shevell M, Ashwal S, Donley D, Flint J, Gingold M, Hirtz D, et al. Practice parameter: Evaluation of the child with global developmental delay Report of the Quality Standards Subcommittee of the American Academy of Neurology and The Practice Committee of the Child Neurology Society. Neurology. 2003;60(3):367-80.

3. Lowe L, McMillan AG, Yates C. Body Weight Support Treadmill Training for Children With Developmental Delay Who Are Ambulatory. Pediatric physical therapy: the official publication of the Section on Pediatrics of the American Physical Therapy Association. 2015;27(4):386.

4. Araujo LB, Mélo TR, Israel VL. Low birth weight, family income and paternal absence as risk factors in neuropsychomotor development. J. Hum. Growth Dev. 2017;27(3):272-80. http://dx.doi. org/10.7322/jhgd.124072

5. Rydz D, Shevell MI, Majnemer A, Oskoui M. Developmental Screening. J Child Neurol. 2005;20(1):4-20.

6. Brito CML, Vieira GO, Costa MdCO, Oliveira NFd. Neuropsychomotor development: the Denver scale for screening cognitive and neuromotor delays in preschoolers. Cad. Saúde Pública. 2011;27(7):1403-14.

7. Guimarães FAdB, Assis CD, Vieira MEB, Formiga CKMR. Avaliação de material didático elaborado para orientação de cuidadores e professores de creches sobre o desenvolvimento infantil. Rev. bras. crescimento desenvolv. hum. 2015;25(1):27-40.

8. Campos MM, Esposito YL, Bhering E, Gimenes N, Abuchaim B. A qualidade da educação infantil: um estudo em seis capitais brasileiras. Cad Pesqui. 2013;41(142):20-54. http://dx.doi.org/10.1590/ S0100-15742011000100003

9. Araujo LB, Novakoski KRM, Bastos MSC, Mélo TR, Israel VL. Caracterização do desenvolvimento neuropsicomotor de crianças até três anos: o modelo da CIF no contexto do NASF. Cad Bras Ter Ocup. 2018 in press;26(3). https://doi.org/10.4322/2526-8910. ctoAO1183

10. Shonkoff JP. Protecting brains, not simply stimulating minds. Science. 2011;333(6045):982-3.

11. Center on the Developing Child at Harvard University. Construção do sistema de "Controle de Tráfego Aéreo" do cérebro como as primeiras experiências moldam o desenvolvimento das funções executivas Estudo. n. 11 2011. Available from: http:\|www.developingchild.harvard.edu.

12. Morgan C, Novak I, Dale RC, Guzzetta A, Badawi N. GAME (Goals-Activity-Motor Enrichment): protocol of a single blind randomised controlled trial of motor training, parent education and environmental enrichment for infants at high risk of cerebral palsy. BMC neurology. 2014;14(1):1.

13. Morgan C, Novak I, Badawi N. Enriched environments and motor outcomes in cerebral palsy: systematic review and meta-analysis. Pediatrics. 2013;132(3):e735-e46. DOI: 10.1542/peds.2012-3985

14. Santos D, Gonçalves V. Influência de práticas maternas no desenvolvimento motor de lactentes do $6^{\circ}$ ao $12^{\circ}$ meses de vida. Rev bras fisioter. 2006;10(2):225-31.

15. Silva AZd, Vojciechowski AS, Mélo TR, Yamaguchi B, Touchan AS, Bertoldi AS, et al. Avaliação neuropsicomotora e classificação funcional em escolares de 10 a 12 anos da rede pública. Rev Ter Ocup Univ Sao Paulo. 2016;27(1):52-62. http://dx.doi.org/10.11606/ issn.2238-6149.v27i1p52-62
16. Chan A-W, Tetzlaff JM, Gøtzsche PC, Altman DG, Mann H, Berlin JA, et al. SPIRIT 2013 explanation and elaboration: guidance for protocols of clinical trials. Bmj. 2013;346:e7586.

17. IBGE. Disponível em:< http://www.censo2010.ibge.gov.br/> 2010 [cited 12].

18. Santo HE, Daniel FB. Calcular e apresentar tamanhos do efeito em trabalhos científicos (1): As limitações do $\mathrm{p}<0,05$ na análise de diferenças de médias de dois grupos. R P I C S. 2015;1(1):3-16.

19. Venturella CB, Zanandrea G, Saccani R, Valentini N. Desenvolvimento motor de crianças entre 0 e 18 meses de idade: Diferenças entre os sexos. Motricidade. 2013;9(2):3-12.

20. Gerzson LR, Catarino BM, Andara K, Demarco P, Palma MS, Almeida CSd. Frequência semanal de um programa de intervenção motora para bebês de berçário. Fisioter. Pesqui. 2016;23(2):178-84.

21. Guimarães EL, Tudella E. Reflexos primitivos e reações posturais como sinais indicativos de alterações neurossensoriomotoras em bebês de risco. Pediatria (São Paulo). 2003;25(1/2):28-35.

22. Saccani R, Valentini NC, Pereira KR. New Brazilian developmental curves and reference values for the Alberta infant motor scale. Infant Behavior and Development. 2016;45:38-46.

23. Drachler MdL, Marshall T, De Carvalho Leite JC. A continuous-scale measure of child development for population-based epidemiological surveys: a preliminary study using Item Response Theory for the Denver Test. Paediatr Perinat Epidemiol. 2007;21(2):138-53.

24. Blauw-Hospers $\mathrm{CH}$, Hadders-Algra M. A systematic review of the effects of early intervention on motor development. Dev Med Child Neurol. 2005;47(06):421-32.

25. Timmons BW, LeBlanc AG, Carson V, Connor Gorber S, Dillman C, Janssen I, et al. Systematic review of physical activity and health in the early years (aged 0-4 years). Appl Physiol Nutr Metab. 2012;37(4):773-92.

26. Gallahue DL, Ozmun JC, Goodway JD. Compreendendo o Desenvolvimento Motor-: Bebês, Crianças, Adolescentes e Adultos: AMGH; 2013.

27. Ratliffe KT. Fisioterapia na clínica pediátrica: guia para a equipe de fisioterapeutas: Santos; 2002.

28. Formiga C, Pedrazzani E, Tudella E. Intervenção precoce com bebês de risco. São Paulo: Atheneu; 2010.

29. Paesani G. 120 jogos e percursos de psicomotricidade: crianças em movimento. Petrópolis: Editora Vozes; 2014.

30. Dahab KS, McCambridge TM. Strength training in children and adolescents: raising the bar for young athletes? Sports Health. 2009;1(3):223-6.

31. Patel M. Action observation in the modification of postural sway and gait: Theory and use in rehabilitation. Gait \& posture. 2017;58:115-20.

32. Burgess JD, Lum JA, Hohwy J, Enticott PG. Echoes on the motor network: how internal motor control structures afford sensory experience. Brain Struct Funct. 2017:1-24.

33. Mélo TR, Araujo LBd, Novakoski KRM, Israel VL. Sistematização de instrumentos de avaliação para os dois primeiros anos de vida de bebês típicos ou em risco conforme o modelo da CIF Fisioter Pesq in press.

34. Frankenburg WK, Dodds J, Archer P, Bresnick B, Maschka P, Edelman N, et al. Manual técnico (Adaptação brasileira). In: Sabatés ALT, editor. The Denver II: a major revision and restandardization of the Denver Developmental Screening Test. São Paulo: Hogrefe; 2018. 
35. Souza SCd, Leone C, Takano OA, Moratelli HB. Desenvolvimento de pré-escolares na educação infantil em Cuiabá, Mato Grosso, Brasil. Cad saúde pública. 2008;24(8):1917-26.

36. Darrah J, Bartlett D, Maguire TO, Avison WR, Lacaze-Masmonteil T. Have infant gross motor abilities changed in 20 years? A re-evaluation of the Alberta Infant Motor Scale normative values. Dev Med Child Neurol. 2014;56(9):877-81.

37. Manacero S, Nunes ML. Avaliação do desempenho motor de prematuros nos primeiros meses de vida na Escala Motora Infantil de Alberta (AIMS). J Pediatr. 2008;84(1):53-9.

38. Piper MC, Darrah J. Alberta Infant Motor Scale (AIMS). Philadelphia: Saunders 1994.

39. Saccani R, Valentini NC. Curvas de referência da Escala Motora Infantil de Alberta: percentis para descrição clínica e acompanhamento do desempenho motor ao longo do tempo. J Pediatr. 2012;88(1):40-7.

40. Caçola PM, Gabbard C, Montebelo MI, Santos DC. The new affordances in the home environment for motor development-infant scale (AHEMD-IS): Versions in English and Portuguese languages. Braz J Phys Ther. 2015 (AHEAD):00-.

41. Damiano DL. Rehabilitative therapies in cerebral palsy: the good, the not as good, and the possible. J Child Neurol. 2009;24(9):1200-4.

42. Mélo TR, Araujo LB, Yamaguchi B, Ferreira MdP, Israel VL. Quality of life and neuropsychomotor development of infants 4-18 months in daycare center Ciência \& Saúde Coletiva in press.

43. Varni JW, Limbers CA, Neighbors K, Schulz K, Lieu JE, Heffer RW, et al. The PedsQL TM Infant Scales: feasibility, internal consistency reliability, and validity in healthy and ill infants. Qual Life Res. 2011;20(1):45-55.

44. Freitas TC, Gabbard C, Caçola P, Montebelo MI, Santos DC. Family socioeconomic status and the provision of motor affordances in the home. Braz J Phys Ther. 2013;17(4):319-27.

45. do Nascimento Junior JRA, Ferreira L, Vissoci JRN, da Silva PN, Caruzzo NM, Vieira JLL. Nível socioeconômico e affordances do ambiente domiciliar: implicações para o desempenho motor infantil. Rev. Educ. Fís/UEM. 2015;25(4):651-62.

46. ABEP. Critério de classificação econômica Brasil: Associação Brasileira de Empresas de Pesquisa - ABEP.; 2015 [17/04/016]. Available from: http://www.abep.org/criterio-brasil.

47. Moreira RS, Figueiredo EMd. Instruments of assessment for first two years of life of infant. J. Hum. Growth Dev. 2013;23(2):215-21.
48. Ismail FY, Fatemi A, Johnston MV. Cerebral plasticity: windows of opportunity in the developing brain. Eur J Paediatr Neurol. 2017;21(1):23-48.

49. Denboba AD, Sayre RK, Wodon QT, Elder LK, Rawlings LB, Lombardi J. Intensificando o desenvolvimento da primeira infância. 2014. Available from: http://www.fmcsv.org.br/pt-br/acervo-digital/ Paginas/intensificando-o-desenvolvimento-da-primeira-infancia. aspx.

\section{Financial support}

This study was financed in part by the Coordenação de Aperfeiçoamento de Pessoal de Nível Superior - Brasil (CAPES) - Finance Code 001.

\section{Acknowledgements}

The authors would like to thank the Municipal Secretary of Education of Curitiba (Paraná-Brazil), Elisângela Valevein Rodrigues for assistance with English language editing and CAPES for granted support.

\section{Corresponding author}

Tainá Ribas Mélo, PT, Phd.

Coração de Maria Street, number 92, Campus Jardim Botânico, Curitiba, Paraná, Brazil.

Email: ribasmelo@gmail.com

Manuscript received on December 18, 2018

Manuscript accepted on May 12, 2019

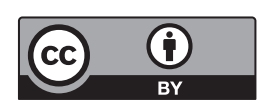

Motriz. The Journal of Physical Education. UNESP. Rio Claro, SP, Brazil - eISSN: 1980-6574 - under a license Creative Commons - Version 4.0 